\title{
HEMODYNAMIC ANDCYTOLOGIC CHANGESINPROSTATE GLANDCAUSED BY CHRONIC HEPATITIS
}

DOI: $10.36740 /$ WLek202104126

\author{
Volodymyr B. Grytsuliak', Mariana M. Vasylechko', Oksana I., Kocherzhat ${ }^{1}$, Oksana I. Hotiur ${ }^{2}$ \\ 'V. STEFANYK PRECARPATHIAN NATIONAL UNIVERSITY, IVANO-FRANKIVSK, UKRAINE \\ 2IVANO-FRANKIVSK NATIONAL MEDICAL UNIVERSITY, IVANO-FRANKIVSK, UKRAINE
}

\begin{abstract}
The aim: Is to determine the features of hemodynamics and the character of structural and functional changes in the prostate gland in middle-aged infertile males in the conditions of chronic hepatitis.

Materials and methods: We studied the features of hemodynamics and structural and functional state of the prostate gland in middle-aged males who had suffered from chronic hepatitis with the help of ultrasound scanning, Color-Doppler sonography, and histology, morphology, and statistics.

Results: It was detected that in 3-5 years after chronic viral hepatitis in middle-aged males (the first period), the volume of the prostate gland increases to $(27.1 \pm 1.2) \mathrm{cm} 3$, and its mass to $(28.0 \pm 1.7) \mathrm{g}$ compared to the control. Blood flow rates in the prostate gland: arterial blood flow velocity, blood flow diastolic velocity, volumetric blood flow are significantly lower than the control ones. Glandular zone surface decreases to $53 \%$ and connective tissue increases to $43 \%$. Epithelium in the secretory area of the gland is compressed.

Conclusions: 1.According to the data of ultrasound diagnostics and Color-Doppler sonography, the volume of the prostate gland increases to $(27.1 \pm 1.8) \mathrm{cm}^{3}$ and its mass to $(28.0 \pm 1.7) \mathrm{g}$ at chronic viral hepatitis, compared to the control $(21.3 \pm 1.5) \mathrm{cm} 3$ and $(24.7 \pm 1.3) \mathrm{g}(\mathrm{p}<0.05)$. Atrophic changes in the prostate gland are manifested with the decreased height of the columnar epithelium of the gland and overgrowth of connective tissue in the stroma of the organ. 2.Angioechometric indices of arterial blood circulation in central and peripheral zone of the prostate decreases to $(7.26 \pm 0.46) \mathrm{cm} / \mathrm{sec}$ and $(7.80 \pm 0.32) \mathrm{cm} / \mathrm{sec}$ respectively compared to the control $(18.30 \pm 3.10) \mathrm{cm} / \mathrm{sec}$ and $(17.70 \pm 2.90) \mathrm{cm} / \mathrm{sec}$. Venous blood flow rates decrease to $(2.45 \pm 0.21) \mathrm{cm} / \mathrm{sec}$ and $(2.60 \pm 0.16) \mathrm{cm} / \mathrm{sec}$ compared to $(5.54 \pm 0.8) \mathrm{cm} / \mathrm{sec}$ and $(5.36 \pm 0.03) \mathrm{cm} / \mathrm{sec}(\mathrm{p}<0.05)$.
\end{abstract}

KEY WORDS: prostate gland, hemodynamics, histostructure, chronic hepatitis

Wiad Lek. 2021;74(4):954-956

\section{INTRODUCTION}

As it is known, the prostate gland serves several important functions in the male reproductive system. In particular, its glandular parenchyma produces mucous secretion which dilutes sperm and improves its motility. It also secretes prostaglandins into the blood what stimulates the testicular hormonal activity of and spermatogenesis $[1,2,3,4,5]$. Acute and chronic prostatitis and prostate adenoma are widely described in the literature $[6,7,8]$, but the state of hemodynamics and structural and functional changes in it at chronic hepatitis remain studied too little that determines the relevance of this study.

\section{THE AIM}

The aim of the study is to determine the features of hemodynamics and the character of structural and functional changes in the prostate gland of middle-aged infertile males with chronic hepatitis.

\section{MATERIALS AND METHODS}

The ultrasound scanning and the Color-Doppler sonography of the prostate gland in 12 middle-aged infertile males (22-35-year-old), diagnosed with chronic hepatitis in anamnesis, were performed in a clinical and diagnostic center on the SIEMENS SONOLINE G60S ultrasound system (Siemens AG, Germany).

We determined the volume of the prostate gland in $\mathrm{cm} 3$, its mass using the formula $\mathrm{m}=\mathrm{V} \times 1.05$, where $\mathrm{V}$ was the volume of the gland, 1.5 was the coefficient. In the mode of color flow mapping, as well as in pulsed-wave Doppler, we evaluated the character of vascular pattern, vessel diameter. The quantitative evaluation was done according to vascular plexus density, the number of vessels VES/cm 3 , and the vessel diameter (VD). Hemodynamics qualitative indicators in the prostate gland were: 1) peak arterial flow rate $(\mathrm{cm} / \mathrm{sec}), 2)$ blood flow diastolic velocity, $\mathrm{DV}(\mathrm{cm} / \mathrm{sec}), 3)$ linear velocity of blood flow $(\mathrm{cm} / \mathrm{sec}), 4)$ perfusion index, PI (RU), 5) resistive index, RI (RU), 6) volumetric blood flow (L/min). In the archive histological micropreparations of 7 prostate biopsies at this pathology collected in the Department of Urology of CNE "Ivano-Frankivsk Regional Clinical Hospital", we detected relative surfaces of glandular and muscular-elastic components, as well as the height of glandular epithelial cells.

Statistical analysis of the received results was done with the help of the Statistica 6 software. 
Table I. The echometric indicators of the prostate gland in middle-aged infertile males after hepatitis

\begin{tabular}{cccccc}
\hline \multirow{2}{*}{ Type of the test } & \multicolumn{5}{c}{ Prostate parameters $\left(\mathbf{M} \pm \mathbf{m}\right.$; $\left.{ }^{*} \mathbf{p}<\mathbf{0 . 0 5}\right)$} \\
\cline { 2 - 6 } & Width & Thickness & Length & Volume & Mass \\
\hline \multirow{2}{*}{ Control } & $75.5 \pm 2.0$ & $24.5 \pm 1.7$ & $22.6 \pm 1.6$ & $21.3 \pm 1.5$ \\
$(\mathrm{~mm})$ & $(\mathrm{mm})$ & $(\mathrm{mm})$ & $\begin{array}{c}24.7 \pm 1.3 \\
(\mathrm{~g})\end{array}$ \\
\hline Chronic hepatitis & $41.2 \pm 1.5^{*}$ & $26.5 \pm 1.4$ & $27.3 \pm 1.2^{*}$ & $27.1 \pm 1.8^{*}$ & $28.0 \pm 1.7^{*}$ \\
\hline
\end{tabular}

Table II. The blood flow indicators in the prostate gland in middle-aged infertile males after chronic viral hepatitis $(M \pm m),(n=19)$

\begin{tabular}{ccc}
\hline Indicators, measurement units & Central zone & Peripheral zone \\
\hline Peak arterial flow rate, $\mathrm{cm} / \mathrm{sec}$ & $7.26 \pm 0.46$ & $7.80 \pm 0.32$ \\
\hline Blood flow diastolic velocity, cm/sec & $2.45 \pm 0.21$ & $2.60 \pm 0.16$ \\
\hline Linear velocity of blood flow, cm/sec & $5.28 \pm 0.23$ & $5.40 \pm 0.22$ \\
\hline Perfusion index, RU & $5.42 \pm 0.23$ & $5.46 \pm 0.18$ \\
\hline IP, RU & $1.18 \pm 0.05$ & $1.20 \pm 0.05$ \\
\hline Resistive index, cm & $0.06 \pm 0.01$ & $0.05 \pm 0.01$ \\
\hline Vascular plexus density, VES/cm ${ }^{3}$ & $0.75 \pm 0.43$ & $0.69 \pm 0.16$ \\
\hline Volumetric blood flow, L/min & $0.03 \pm 0.001$ & $0.01 \pm 0.002$ \\
\hline
\end{tabular}

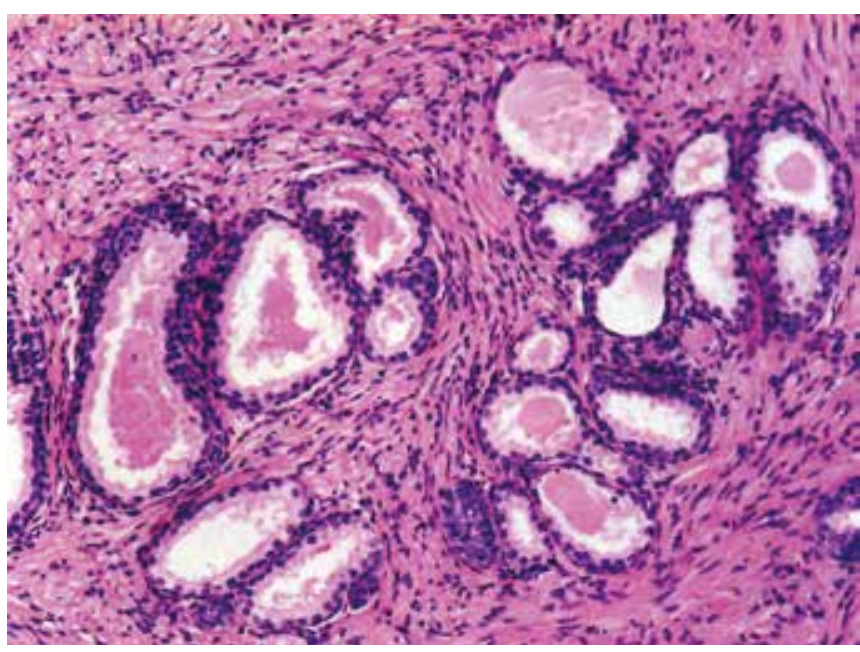

Fig. 1. Expressed overgrowing of connective tissue around prostate particles in a 35-year-old male with chronic hepatitis. Colored with hematoxylin and eosin.

The ethical committee of V. Stefanyk Precarpathian National University did not detect any ethics violations during the study (Record No2 from 20.10.2020).

\section{RESULTS AND DISCUSSION}

According to received data, the volume of the prostate gland increases to $(27.1 \pm 1.2) \mathrm{cm} 3$, and its mass to $(28.0 \pm 1.7) \mathrm{g}$ compared to the control (Table I) in middle-aged infertile males with chronic hepatitis in anamnesis.

Blood flow indicators in the prostate gland show under these circumstances that peripheral parenchyma characterizes by lower vascularization compared to the one in the central zone. The vascular pattern is inhomogeneous, disorganized, with a significant decrease of peak velocities and volumetric blood flow due to stagnation (Table II).

In histological micropreparations of the prostate biopsies, the surface ratio of glandular parenchyma to elastic stroma

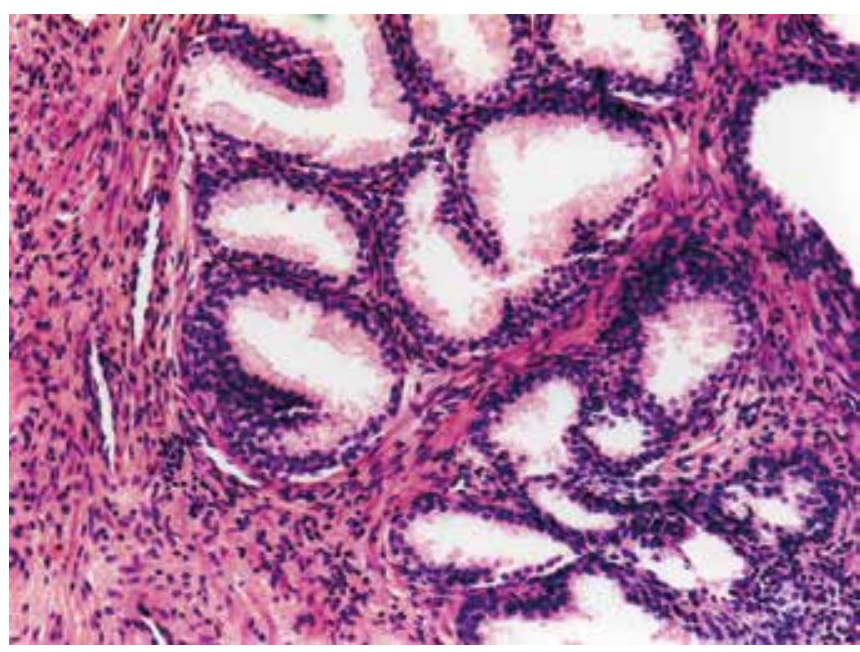

Fig. 2. Terminal secretory zones of the prostate gland in a 32-year-old male are lined with cylindrical epithelium (control). Colored with hematoxylin and eosin.

is $52 \%$ to $98 \%$ compared to the control $70 \%$ to $30 \%$. It has been detected an increased number of particles that undergo atrophic processes with decreasing of the height of glandular epithelium (fig. 1) transforming to cubical or squamous ones. There is overgrowing of connective tissue present.

The middle-aged males of the control group have secretory zones of tubular-alveolar particles in the prostate gland. The epithelium of the terminal zones is cubical or cylindrical. In the part of secretory zones, there is an amorphous exprimate. In the prostate stroma, there is loose and smooth muscle tissue (fig. 2).

The used methods of ultrasound scanning and the Color-Doppler sonography of the prostate gland, color flow mapping, and laboratory tests of ejaculate allowed reaching the set goal.

Received results on structural and functional changes in the prostate gland are original because in the processed literature similar data were not found. 
There is an established fact of the regulatory influence of testicular hormones on the general state of the human body [1]. The decrease of its endocrine activity is considered one of the main causes which accelerate aging processes in the body. But the spermatogenic function of the testes is more important, its disorders cause male infertility.

The data about the blood supply of testicles and prostate gland are presented in many works $[5,7,8]$ but the features of the influence of hepatitis on the blood supply of male reproductive organs in males of reproductive age remain incomplete. This especially concerns the prostate gland, the character of changes in hemomicrocirculatory bed and tortuous spermatic cords, testicle, epididymis at chronic viral hepatitis of the liver.

The authors found out that the ratio between the total lumen of arterial vessels and the volume of the prostate gland change with age $[6,7]$; our data show the influence of viral hepatitis by the increase of the volume of the prostate gland to $(27.1 \pm 1.8) \mathrm{cm} 3$ and its mass to $(28.0 \pm 1.7) \mathrm{g}$ compared to $(21.3 \pm 1.5) \mathrm{cm} 3$ and $(24.7 \pm 1.3) \mathrm{g}$ in the control group $(\mathrm{p}<0.05)$.

According to the data about disorders in hemodynamics presented by us and other researchers $[2,3,4]$, an increase of destructive changes in the wall of the blood vessels of different caliber and ultrastructural rebuild of blood-testis barrier, are ones of the causes in the reduction of germinal epithelium cell layers in tortuous spermatic cords.

Prospects for further studies lie in the study of the influence of chronic hepatitis on the structural and functional state of a testicle and ejaculate.

\section{CONCLUSIONS}

1. According to the data of ultrasound diagnostics and Color-Doppler sonography, the volume of the prostate gland increases to $(27.1 \pm 1.8) \mathrm{cm} 3$ and its mass to $(28.0 \pm 1.7) \mathrm{g}$ at chronic viral hepatitis, compared to the control $(21.3 \pm 1.5)$ $\mathrm{cm} 3$ and $(24.7 \pm 1.3) \mathrm{g}(\mathrm{p}<0.05)$. Atrophic changes in the prostate gland are manifested with the decreased height of the columnar epithelium of the gland and overgrowth of connective tissue in the stroma of the organ.

2. Angioechometric indices of arterial blood circulation in central and peripheral zone of the prostate decreases to $(7.26 \pm 0.46) \mathrm{cm} / \mathrm{sec}$ and $(7.80 \pm 0.32) \mathrm{cm} / \mathrm{sec}$ respectively compared to the control $(18.30 \pm 3.10) \mathrm{cm} / \mathrm{sec}$ and $(17.70 \pm 2.90) \mathrm{cm} / \mathrm{sec}$. Venous blood flow rates decrease to $(2.45 \pm 0.21) \mathrm{cm} / \mathrm{sec}$ and $(2.60 \pm 0.16) \mathrm{cm} / \mathrm{sec}$ compared to $(5.54 \pm 0.8) \mathrm{cm} / \mathrm{sec}$ and $(5.36 \pm 0.03) \mathrm{cm} / \mathrm{sec}(\mathrm{p}<0.05)$.

\section{REFERENCES}

1. Schill W. B., Comhaire F. N., Hargreave T. B. Andrology for the Clinical. Springer-Verlag Berlin Heidelberg. 2011, $800 \mathrm{p}$.

2. Grytsuliak B.V., Dolunko N.P., Popadinec O.H. et al. Kharakter morfofunktsionalnykh zmin v peredmikhuroviy zalozi, zumovlenykh etanolovoyu intoksykatsiyeyu [The nature of morphofunctional changes in the prostate gland, caused by ethanol intoxication]. Bulletin of problems biology and medicine. 2016;2(129):70-73. (in Ukrainian).
3. Gerashchenko S. B., Grytsuliak B. V., Grytsuliak V. B. et al. Osoblyvosti strukturnykh zmin u peredmikhuroviy zalozi v umovakh subtotalnoyi tsyrkuliatornoyi hipoksiyi istymuliatsiyi krovotoku [Pecularties of structural changes in prostate gland in conditions of subtotal hypoxy and blood flow stimulation]. World of Medicine and Biology. 2011;4:26-28. (in Ukrainian).

4. Grytsuliak B.V., GrytsuliakV.B., Dolynko N.P. et al.Strukturno-funktsionalni zminy veredmikhuroviy zalozi cholovikiv zriloho viku pislia perenesenoho epidydymoorkhitu [Structural and functional changes in the prostate gland of mature men after epididymo-orchitis]. Bulletin of problems biology and medicine. 2020;2(156):256-259. (in Ukrainian).

5. Naumov N.P., SheplovP.A., PolozovV.V.The role of antioxidants in prevention of male infertility. Andrology and Genital Surgery. 2019;20(1):13-21.

6. Lytvynets Y. A., Khallo 0. Y. Strukturno-funktsionalni osoblyvosti krovonosnoho rusla i parenkhimy peredmikhurovoyi zalozy pry khronichnomu prostatyti [The structural and functional pecularties of the blood channel and the parenchyma of the prostate gland in case of chronical prostatitis]. Clinical Anatomy and Operative Surgery. 2011;2(10):25-28. (in Ukrainian).

7. Glina S., Glina P. Pathogenic mechanisms linking benign prostatic hyperplasia, lower urinary tract symptoms and erectile dysfunction. TherAdv Urol. 2013;5(4):211-218. doi: 10.1177/1756287213488236.

8. Lesin A. I., Lytvynets Y. A., Seyeniv Y. M. Kombinovana konservatyvna terapiya khvorykh iz symptomamy nyzhnikh sechovykh shliakhiv ta yikh uskladnenniamy [Combined conservative therapy of the patients with symptoms of lower urinary tracts and their complications]. Health of Man. 2009;3:180-183. (in Ukrainian).

The study was done according to the plan of the scientific work of the V. Stefanyk Precarpathian National University and is a part of the scientific and research work of the Department of Human and Animal Anatomy and Physiology "Actual Aspects of Andrology and Spermatogenesis Correction" No of the state registration (0119UC03671).

\section{ORCID and contributionship:}

Oksana I. Hotiur: 0000-0001-9687-0112 A,B,E,F

Volodymyr B. Grytsuliak: 0000-0001-5719-748X ${ }^{B, F}$

Mariana M. Vasylechko: 0000-0001-9640-47X ${ }^{B, D}$

Oksana I. Kocherzhat: 0000-0003-4568-586X ${ }^{B, C}$

\section{Conflict of interest:}

The Authors declare no conflict of interest.

\section{CORRESPONDING AUTHOR Oksana I. Hotiur}

Ivano-Frankivsk National Medical University

17 Fedkovych St., 76008 Ivano-Frankivsk, Ukraine

tel: +380996616005

e-mail:0ksanahotiur@gmail.com
Received: 08.11 .2020
Accepted: 04.03 .2021

A-Work concept and design, B - Data collection and analysis, C - Responsibility for statistical analysis,
D-Writing the article, E-Critical review, F-Final approval of the article 